\title{
KEEPING TECHNICAL EDUCATION ALIGNED TO THE NEEDS AND EXPECTATIONS OF INDUSTRY
}

\author{
Wieslaw GREBSKI, Michalene GREBSKI \\ The Pennsylvania State University
}

\begin{abstract}
:
Paper describes the continuous quality improvement procedures used by the author to keep the General Engineering program at Penn State Hazleton aligned to the needs and expectations of industry. The paper addresses the procedure for the development of program educational objectives which are the goals of the program. The goals of the program are defined jointly by industry leaders and former Engineering graduates as well as the Engineering faculty. The paper also focuses on the development of the student outcomes which is the body of knowledge that every graduate should have at the day of graduation. The paper also explains the process for collecting data for the purpose of assessing the level of attainment of program objectives and student outcomes. Based on the data which is being collected on an ongoing basis, the necessary corrective actions are implemented. This is happening on the program level as well as the course level. The necessary changes on the course level are happening every semester. The adjustments to the Engineering curriculum are being made yearly usually during the summer months. The paper focuses on the constant need for revising the curriculum in order to stay current with technology.
\end{abstract}

Key words: Technical Education, Workforce Development, Curriculum Development, Quality Improvement

\section{INTRODUCTION}

Engineering and technical education are providing the workforce which is required by industry. The educational institutions and industry as well as the community are part of the same ecosystem. Industry relies on the educational institutions to provide a highly trained workforce which satisfies the constantly changing demands and expectations of industry. Educational institutions rely on industry to provide internship opportunities for students and consulting opportunities for faculty as well as feedback on the educational and training requirements for their future workforce. Communities depend on both the educational institutions and industry to provide economic prosperity and growth of the area [6].

The timetable for students to complete the requirements for an Engineering degree is approximately four to five years. The requirements of industry related to technical skills are changing annually. Therefore, Engineering programs have to be flexible and adjust their curriculum on a yearly basis. The continuous quality improvement process based on data collection, analysis of data and incorporating corrective actions is an absolute necessity for the sustainability of any engineering program.

For the purpose of continuous quality improvement, every Engineering program needs to develop program educational objectives which are defined as the achievement of their graduates three to five years after their graduation. Program educational objectives are being used to recruit perspective students [4]. Program educational objectives are also being used by industry to recruit graduates. Engineering programs are constantly collecting data on the per- centage of graduates who either meet or do not meet program educational objectives. Access to that data is available to perspective students.

Based on the educational objectives, the engineering faculty and leaders from industry develop student outcomes which are defined as the body of knowledge that the graduates have on the day of graduation. The student outcomes are a basis for curriculum development. The development of the curriculum is done by the Engineering faculty. Every course that a student takes in the Engineering curriculum is linked to the body of knowledge described by the student outcomes [5]. Therefore every course is a significant component of the Engineering curriculum.

\section{DEFINING AND UPDATING PROGRAM EDUCATIONAL OBJECTIVES}

The educational objectives of the General Engineering (GE) program is to prepare graduates who, during the first few years of professional practice will:

- be employed by industry or government in the fields, such as, design, research and development, experimentation and testing, manufacturing, and technical sales,

- assume an increasing level of responsibility and leadership within their respective organizations,

- communicate effectively and work collaboratively in multidisciplinary and multicultural work environments,

- recognize and understand global, environmental, social, and ethical contexts of their work, 
- progress to an advanced degree and certificate programs and be committed to lifelong learning to enhance their careers and provide flexibility in responding to changing social and technical environments.

Program educational objectives are listed in the promotional materials for the GE program.

The educational objectives of the GE program can be summarized as providing graduates with knowledge of the concepts and theories of modern electro-mechanical systems sufficient to permit them to become effective designers, operators, testers and maintainers of modern systems. Furthermore, the objectives are expected to prepare graduates to become effective team members and effective communicators in modern, highly technical industrial environments.

The program educational objectives were developed by the Engineering faculty in conjunction with the Industrial Advisory Committee representing local industry.

The educational objectives and outcomes for the GE program are being reviewed annually and aligned with the needs, constituencies and mission of the institution.

\section{DEFINING STUDENT OUTCOMES}

Student outcomes for the General Engineering major are the body of knowledge and skills that students will have at the day of graduation.

To support the achievement of educational objectives, the following student outcomes are integrated into the General Engineering program.

Graduates of the General Engineering program shall be able to:

1. Apply knowledge of mathematics, science, and engineering.

2. Design and conduct experiments, as well as to analyze and interpret data.

3. Design a system, component, or process to meet desired needs within realistic constraints such as economic, environmental, social, political, ethical, health and safety, manufacturability, and sustainability.

4. Function on multidisciplinary teams.

5. Identify, formulate and solve engineering problems.

6. Demonstrate an understanding of professional and ethical responsibility.

7. Communicate effectively.
8. Demonstrate the understanding of the impact of engineering solutions in a global, economic, environmental and societal context.

9. Recognize the need for, and an ability to engage in lifelong learning.

10. Demonstrate knowledge of contemporary issues.

11. Use the techniques, skills and modern engineering tools necessary for engineering practice.

The student outcomes are embedded in all required GE courses. They are maintained and annually reviewed by the GE Curricular Committee.

\section{RELATIONSHIP OF STUDENT OUTCOMES TO PROGRAM EDUCATIONAL OBJECTIVES AND STUDENT OUTCOMES}

Mapping between the program educational objectives and the student outcomes is illustrated in Table 1 Each educational objective is reflected and corresponds to one or more program outcomes.

The mapping between student outcomes and individual courses are shown in Table 2. Every student outcome is reflected in at least two courses. The level of attainment of the student outcomes is being assessed in selected primary junior and senior year courses.

Note: "P" in Table 2 indicates a course where a specific outcome is being assessed and evidence is being collected.

\section{ASSESSMENT OF THE ATTAINMENT OF PROGRAM EDUCA- TIONAL OBJECTIVES AND STUDENT OUTCOMES}

Several quantitative and qualitative processes are used to collect data on the success of GE graduates in achieving the Program Educational Objectives and Student Outcomes. The quantitative processes are:

\section{Class-specific Grading Assessments of Student Outcomes}

All faculties use a variety of traditional assessment and grading methods (exams, out-of-class assignments, projects, etc.). These grading instruments are correlated with student outcomes via the course syllabi. Syllabi developed by individual faculty must explicit references to student outcomes expected of each GE course. Generally, these student outcomes are included as statements in course syllabi so that students are aware of course expectations from the beginning of the course. Further, faculty is expected to tailor a selection of their grading activities to the specific assessment of student performance with respect to the specific student outcomes assigned to their courses.

Table 1

Mapping of student outcomes to program educational objectives

\section{Program Objectives for General Engineering Major}

Be employed by industry or government in the fields, such as, design, research and development, experimentation and testing, manufacturing, and technical sales.

Assume an increasing level of responsibility and leadership within their respective organizations.

Communicate effectively and work collaboratively in multidisciplinary and multicultural work environments.

Recognize and understand global, environmental, social, and ethical contexts of their work.

Progress to an advanced degree and certificate programs and be committed to lifelong learning to enhance their careers and provide flexibility in responding to changing social and technical environments.
Student Outcomes for General Engineering Major

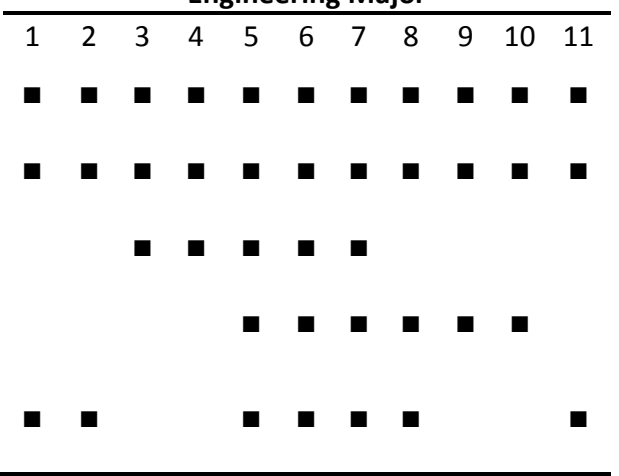


Table 2

Mapping of the student outcomes to required courses in the GE program

\begin{tabular}{|c|c|c|c|c|c|c|c|c|c|c|c|c|c|c|c|c|c|c|c|c|}
\hline & $\begin{array}{l}\text { GE STUDENT OUTCOMES } \\
\text { Students should have: }\end{array}$ & $\begin{array}{c}\text { EDSGN } \\
100\end{array}$ & $\begin{array}{c}\text { EMCH } \\
211\end{array}$ & $\begin{array}{c}\text { EMCH } \\
213\end{array}$ & $\begin{array}{c}\text { EE } \\
210\end{array}$ & $\begin{array}{l}\text { ME } \\
300\end{array}$ & $\begin{array}{c}\text { EE } \\
314\end{array}$ & $\begin{array}{l}\text { EME } \\
303\end{array}$ & $\begin{array}{l}\text { ME } \\
345\end{array}$ & $\begin{array}{c}\text { EGEE } \\
\mathbf{3 0 2}\end{array}$ & $\begin{array}{c}\text { ENGR } \\
350\end{array}$ & $\begin{array}{l}\text { NUCE } \\
401\end{array}$ & $\begin{array}{c}\text { EGEE } \\
441\end{array}$ & $\begin{array}{c}\mathrm{EE} \\
485\end{array}$ & $\begin{array}{l}\text { EGEE } \\
437\end{array}$ & $\begin{array}{c}\text { EGEE } \\
438\end{array}$ & $\begin{array}{c}\text { EE } \\
488\end{array}$ & $\begin{array}{c}\text { EGEE } \\
420\end{array}$ & $\begin{array}{l}\text { ENGR } \\
490 W\end{array}$ & $\begin{array}{l}\text { ENGR } \\
491 W\end{array}$ \\
\hline 1 & $\begin{array}{l}\text { Apply knowledge } \\
\text { of mathematics, science, } \\
\text { and engineering }\end{array}$ & & XP & $x$ & & $x$ & XP & $x$ & & $\mathrm{x}$ & XP & $x$ & & $X$ & & $x$ & $x$ & & $x$ & $x$ \\
\hline 3 & $\begin{array}{l}\text { Design and conduct experiments, } \\
\text { as well as to analyze and interpret } \\
\text { data } \\
\text { Design a system, component, or } \\
\text { process to meet desired needs } \\
\text { within realistic constraints such }\end{array}$ & $\mathrm{XP}$ & & & & & & & $\mathrm{XP}$ & & & & & & & & & $\mathrm{x}$ & & \\
\hline & $\begin{array}{l}\text { as economic, environmental, } \\
\text { social, political, ethical, health } \\
\text { and safety, manufacturability, } \\
\text { and sustainability }\end{array}$ & & & & & & & & & & $\mathrm{XP}$ & & $x$ & & $x$ & $\mathrm{x}$ & & $x$ & & XP \\
\hline 4 & $\begin{array}{l}\text { Function on multidisciplinary } \\
\text { teams }\end{array}$ & $\mathrm{x}$ & & & & & & & & $X$ & & & & & & & & & XP & XP \\
\hline 5 & $\begin{array}{l}\text { Identify, formulate, } \\
\text { and solve engineering problems }\end{array}$ & & & & XP & $x$ & $X$ & XP & & & & & & & & & & & & $x$ \\
\hline 6 & $\begin{array}{l}\text { Demonstrate } \\
\text { an understanding } \\
\text { of professional and ethical } \\
\text { responsibility }\end{array}$ & $\mathrm{x}$ & & & & & & & & & & $\mathrm{XP}$ & & & & & & & $x$ & $X P$ \\
\hline 7 & Communicate effectively & $X P$ & & & & & & & $x$ & & & & & & $X$ & & & & $X$ & XP \\
\hline 8 & $\begin{array}{l}\text { Demonstrate } \\
\text { and understand the impact } \\
\text { of engineering solutions } \\
\text { in a global, economic, } \\
\text { environmental, and societal } \\
\text { context }\end{array}$ & $\mathrm{XP}$ & & & & & & & & & & $\mathrm{XP}$ & & $\mathrm{x}$ & & & & & & $x$ \\
\hline 9 & $\begin{array}{l}\text { Recognize the need for, and an } \\
\text { ability to engage in life-long } \\
\text { learning }\end{array}$ & $\mathrm{XP}$ & & & & & & & & & & & & & & & & & XP & \\
\hline 10 & $\begin{array}{l}\text { Demonstrate a knowledge } \\
\text { of contemporary issues }\end{array}$ & & & & & & & & & & & & & $\mathrm{XP}$ & $X$ & $X$ & XP & & & \\
\hline
\end{tabular}

Semester Course Assessments Using ANGEL Data

Measurement and Evaluation of the GE (MEGE) system is an ANGEL-based, on-line data collection system, used by all GE faculty every semester to evaluate the effectiveness of their courses in achieving the student outcomes assigned to those courses. The measurement and evaluation system collects three distinct sets of data: the instructor's assessment of the performance of each individual student with respect to each student outcome associated with a course, the instructor's self-assessment of how well each student outcome was covered by the course offered that semester and each student's perspective on how well he or she understands or can perform each outcome associated with the course. A three-point scoring scale is used for all the measurement and evaluation assessments: $0=$ "outcome not achieved," 1 = "outcome achieved," and 2 = "outcome exceeded". The measurement and evaluation results provide an overall picture of the course and program success in achieving planned student outcomes.

In addition to these quantitative assessment tools, several qualitative assessment processes and data collection tools are used to evaluate the quality of the GE program. These include:

\section{University-sponsored Student Ratings of Teaching Effec- tiveness (SRTES):}

Every semester the University mandates that all instructors conduct SRTEs. The SRTE provides students an oppor- tunity to evaluate both the quality of courses and the quality of instruction in courses. Input to the SRTEs is done anonymously and outside the presence of the course faculty to engender frank and explicit responses from students. SRTE results are compiled by the University and returned to the Director of Academic Affairs of the campus, who then shares the compiled results with the faculty, and if appropriate, identifies actions that should be taken to improve results. The SRTEs are also a University-mandated element in annual faculty performance reviews.

\section{Exit Interviews of Graduating Seniors:}

Every spring the Career Services office conducts exit surveys of all graduating students. These surveys provide the most immediate information on the employment prospects of outgoing graduates and an indication of those who plan to pursue further education in the immediate time frame. The surveys also provide information on the companies hiring GE graduates, which is valuable information both for informing aspiring GE students and for recruiting members for the industrial advisory committee.

Industrial Advisory Committee Exit Interviews of Graduating Seniors:

The Industrial Advisory Committee (IAC) is a critical source of feedback on the effectiveness of the GE program in satisfying local industry needs. Members of the committee also offer a special perspective on the skills and ca- 
pabilities that graduates need to succeed in the industries they represent. For that reason, the IAC is asked every spring to conduct, as a group, a face-to-face exit interview with all graduating GE students. The process is unscripted. IAC members are simply requested to discuss with the students their experiences in and reactions to the GE program as they prepare to graduate, and also to provide their reactions regarding the preparedness of graduates to enter the local work force. IAC members are asked only to summarize the important facts and comments from the interviews and to offer any suggestions that may arise as a result of the sessions.

\section{Alumni and Employer Surveys}

Alumni and employer surveys are conducted every two to three years and provide the most valuable feedback in assessing program educational objectives. Similar surveys are being sent to the alumni (former graduates) as well as their employers. The alumni are being asked to assess to what extent the program met the educational objectives. They are also asked to assess the quality of instruction for every course that they took. (They are assessing faculty as well as the curriculum.) The alumni are also being asked to suggest any curricular changes that they feel would be helpful and were not sufficiently addressed in the curriculum.

The employer survey is focusing on the employer's rate of satisfaction with the level of preparation of the graduates. The employer is also asked to list the skills which are needed or will be needed in the future and are not sufficiently addressed in the curriculum.

\section{CONTINUOUS QUALITY IMPROVEMENT PROCEDURE}

Continuous Quality Improvement Procedure on the Program Level

At the end of each academic year, the GE Program Coordinator prepares a written report assessing the performance of the GE program with respect to attainment of the Program Educational Objectives and Student Outcomes. This report uses the course reports prepared by faculty and aggregate course and program data from the measurement and evaluation system. The purpose of the report is similar to the course evaluations, i.e., to identify potential weaknesses, define actions to remove the weaknesses, and monitor the effectiveness of changes [3].

Continuous Quality Improvement Procedure on the Course Level

Responses to the measurement and evaluation surveys and the results of SRTEs are used by faculty every semester to identify strengths and weaknesses in course delivery for that semester and to identify areas for improvement or correction. The results of these assessments are documented in written reports each semester, and copies are maintained by the program coordinator for three years.

\section{CONCLUSIONS}

The Engineering program needs to create and maintain an ecosystem. It needs to maintain an ongoing relationship with former graduates (alumni of the program) and local industry as well as the community. Local industry helps the Engineering program update its educational objectives according to the current and predicted industry needs. By surveying industry and former graduates, the Engineering program receives the data which is needed for the continuous quality improvement process. This data needs to be analyzed annually for the purpose of incorporating corrective actions.

The Engineering curriculum needs the flexibility to rapidly change and be aligned with the program educational objectives. The Engineering program needs to maintain a working relationship with community leaders and local school districts in order to secure a pipeline of incoming students [2].

The methodology described in the paper has been successfully used by the author in managing the General Engineering program at Penn State Hazleton [1].

\section{REFERENCES}

[1] S. Cai and W. Grebski. „Improve Retention through Implementation of "Toy FUN" Projects into Fundamental Engineering Classes", in Proc. IAJC-ASEE, Joint International Committee, 2011.

[2] W. Grebski and S. Cai. "Partnership with STEM High School as a Recruiting Tool for Engineering Program", in Proc. The $10^{\text {th }}$ Latin American and Caribbean Conference for Engineering and Industry, Panama City, Panama, 2012.

[3] W. Grebski. „Teaching Mathematics as a Global Challenge for Engineering Education", in Proc. ICIE Conference, 2015.

[4] W. Grebski. „Recruitment of Engineering Students through Community-Based Programs", in Proc. The $12^{\text {th }}$ Latin American and Caribbean Conference on Engineering and Industry, Guayaquil, Ecuador, 2014.

[5] W. Grebski and K. Dudeck. „Portable Photovoltaic Laboratory for In-Service Teacher Workshops”, in Proc. Annual Conference American Society for Engineering Education, Atlanta (GA), USA, 2013.

[6] W. Grebski. „Energy Sustainability from an Engineering and Business Perspective", Intensive Program: Sustainability Management and Technology International Conference, 2012.

Wieslaw Grebski, Ph.D., Michalene Grebski, M.A.

The Pennsylvania State University

76 University Drive, Hazleton, PA 18202, USA

e-mail:wxg3@psu.edu 